\author{
Nataliia Barabash \\ Department of Economics and Business Finance \\ Kyiv National University of Trade and Economics, Kyiv, Ukraine \\ E-mail: barabash_n@ukr.net \\ ORCID: https://orcid.org/0000-0002-1011-527X \\ ResearcherID: https://publons.com/researcher/2217788/nataliya-barabash/
}

Tetiana Pashkuda

Department of Economics and Business Finance

Kyiv National University of Trade and Economics, Kyiv, Ukraine

E-mail: tanya.ripa@ukr.net

ORCID: https://orcid.org/0000-0002-0490-9321

ResearcherID: http://www.researcherid.com/rid/Z-1105-2018

\title{
Forecasting changes in the structure of assets and capital of agricultural enterprises
}

\begin{abstract}
The purpose of the study is to develop methodological approaches to forecasting changes in the structure of assets and capital of agricultural enterprises. Methodology. The information base of the article is presented by scientific works of domestic and foreign scientists. The research is based on scientific methods, among which it is expedient to distinguish: analysis and synthesis, comparison, idealization, and abstraction, as well as systematization and generalization - during the formulation of conclusions as a result of the study. Results. It is established that the agricultural sector of Ukraine has significant potential for further growth, but a number of problems hinder its development. Today, the stimulus is the system of land use and land relations, put into effect by lifting the moratorium on land sales. At present, the consequences of such reforms are unpredictable, as there are no clear and transparent rules of the "game» in the sector. It is found out that the most powerful participants in the agricultural market are agricultural holdings, which determine one of the goals of their activities is the development of infrastructure and expansion of influence in foreign markets. In modern economic conditions, the agricultural sector brings 15 $20 \%$ of Ukraine's GDP annually, and despite the crisis of recent years, provides the population with high-quality products of its own production. Practical implications. One of the main problems in the implementation of working capital management policy is to determine the required amount and optimal composition, which is able to ensure the continuity of the enterprise, the maximum level of efficiency of funds. These problems are solved by forecasting the structure of working capital and forecasting its optimal amount. The urgency of the issue increases due to the fact that the problem of predicting the optimal size and structure of assets and capital challenges is caused by macroeconomic and macro-financial instability. Value/originality. Methodical approaches to forecasting changes in the structure of assets and capital are considered. It is proposed to use a system of indicators for calculations, including the following: growth rate of production and sales, a growth rate of product prices, projected operating costs, non-current assets at the beginning of the forecast period, projected investment, average depreciation rate of non-current assets, duration of production turnover inventories, the duration of collection of receivables, the average share of retained earnings in total profit from sales, the basic volume of production and sales, registered and annual invested capital of the enterprise.
\end{abstract}

DOI: https://doi.org/10.30525/2500-946X/2021-2-9

\section{Introduction}

The agricultural sector of any country directly or indirectly affects the material well-being of each member of society. About $50 \%$ of all goods exported by Ukraine are products of the agro-industry and food industry, which are closely related. In this regard, the significant role of the agricultural sector in the socio-economic development of the country is to have a positive impact on other sectors of the economy.

The importance of economic development of the agricultural sector of Ukraine for the economy as a whole

\author{
Keywords \\ The agricultural sector, enterprise, \\ net profit, profitability, assets, \\ capital, life cycle
}

JEL: M22, G31, G32, L81

lies in the rapid growth of production and exports in recent decades. As a result of hostilities in the West of the country, a sharp decline in industrial production and metallurgical exports led to an accelerated restructuring of Ukraine's economy, significantly increasing the importance of the agricultural sector in its structure and exports.

Improving the management system of agricultural enterprises through the adoption of the Law of Ukraine «On Amendments to Certain Legislative Acts of Ukraine on the Conditions of Circulation of Agricultural Land» provides for the introduction of modern management achievements. 
The constant movement and change of assets in the economy and their role in ensuring all stages of the production and commercial cycle necessitates the study of the problem of managing changes in the structure of assets and capital, as this is the most important part of financial management.

One of the main problems in implementing the policy of working capital management is to determine the required amount and the optimal composition that is able to ensure the continuity of the enterprise, the maximum level of value for money. These problems are solved by forecasting the structure of working capital and forecasting its optimal amount.

The urgency of the issue increases due to the fact that the problem of predicting the optimal size and structure of assets and capital challenges caused by macroeconomic and macro-financial instability. This requires the addition of theoretical knowledge about methods and approaches to forecasting changes in assets and capital, as well as their active implementation in the process of enterprise management.

\section{Economic characteristics of the agricultural sector of Ukraine}

In particular, the agricultural sector has a number of features that distinguish it from others, namely [1, p. 212]:

1. Agricultural enterprises operate in conditions of risk and uncertainty, because in agriculture the economic process of reproduction is closely intertwined with biological processes.

2. Agricultural production is carried out in different soil and climatic conditions (good, medium and bad), which directly affects the results of economic activity of enterprises.

3. In contrast to industry, the process of agricultural production involves not three but four resources, such as fixed and working capital, live labor and land, and land in agriculture is the main means of production.

4. Agricultural production is characterized by seasonality of production, which is manifested in the uneven use of labor, means of production, as well as in the uneven flow of products and income during the year.

5. Agriculture is a credit-capacious industry that cannot develop normally without additional financial resources.

6. Agriculture is a less investment-attractive sector compared to a number of other sectors of the economy, due to the long period of agricultural production.
7. In agriculture, compared to other industries, the process of production management is significantly complicated.

For the economic characteristics of the agricultural sector of Ukraine, it is advisable to analyze the dynamics of the country's development during 2010-2020, to consider the main trends and to draw appropriate conclusions.

The dynamics of the number of business entities in Ukraine during 2010-2019 is presented in Figure 1.

The presented information indicates fluctuations in the number of business entities in Ukraine during the study period and their reduction as a whole. The largest number of them was recorded in 2010 and amounted to 2183928 units. Since 2014, there had been a gradual decrease in the number of business entities and only since 2018 the situation had improved. Such dynamics is due to the crisis of the economy and the increase in the number of bankrupt enterprises. Based on statistics, it is established that bankruptcy is one of the biggest problems of the domestic economy - almost 30\% of enterprises in 2020 suffered a loss.

The structural sector of the economy is trade, including activities of agricultural enterprises that sell their own products. Net profit of enterprises involved in agriculture is 81129.2 thousand UAH. We note that $17.4 \%$ of agricultural enterprises in 2020 suffered a loss, while in 2010 almost every second enterprise in this area was unprofitable.

The profitability of operating and all activities of agricultural enterprises is presented in Figure 3. The highest level of profitability of operating activities of agricultural enterprises was recorded in 2015, while the lowest - in 2013. In recent years, we have seen slight fluctuations in the indicator, but no positive changes have taken place.

According to LLC «BAKER TILLY UKRAINE»[3] the largest agricultural holdings in Ukraine are Kernel (trademarks «Shchedry Dar», «Stozhar», «Chumak», "Olio», «Maryndo», etc.), Agro-industrial holding «MHP» (trademarks «Nasha Ryaba», «Lehko!», «Baschinsky», etc.), UkrLandFarming PLC (main activities - crop production, animal husbandry, etc.), Continental Farmers Group (main activity - crop production). At the same time, Kernel has 524 thousand hectares of land, but the production capacity and staff are not the largest among competitors (Figure 4, Figure 5).

The land bank of $\mathrm{AH}$ «MHP» is less by 144 thousand hectares, however the holding has 2,2 times more employees, than the largest landowner. In 2020, the land bank of UkrLandFarming PLC almost caught up with Kernel,

\section{8}

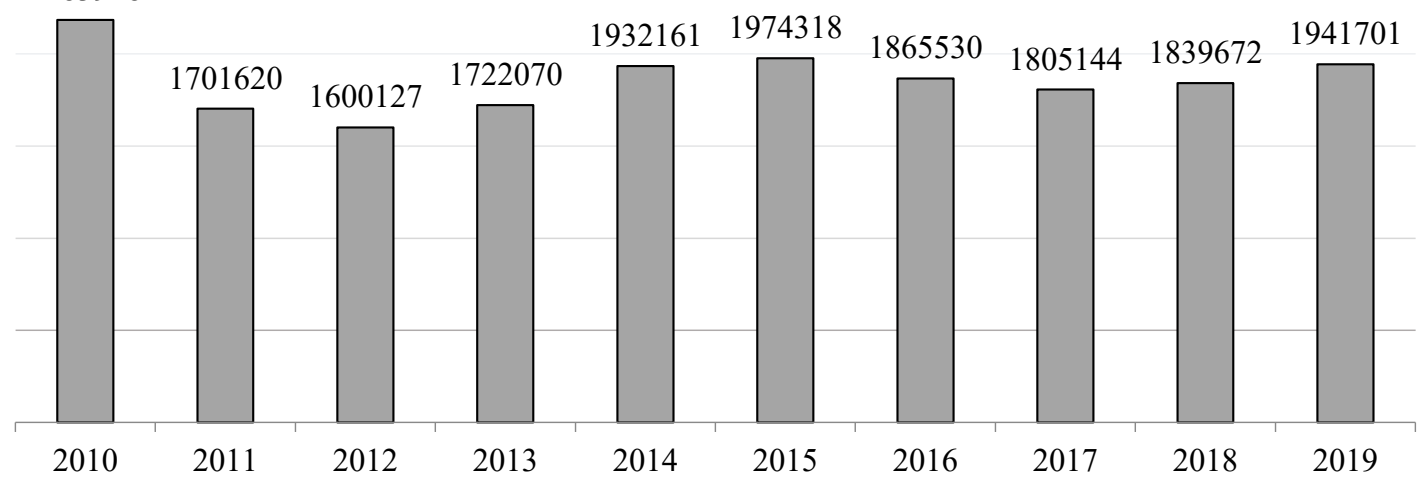

FIGURE 1 Dynamics of change in the number of business entities of Ukraine for 2010-2019 Source: developed on the basis of data from the State Statistics Service of Ukraine [2] 


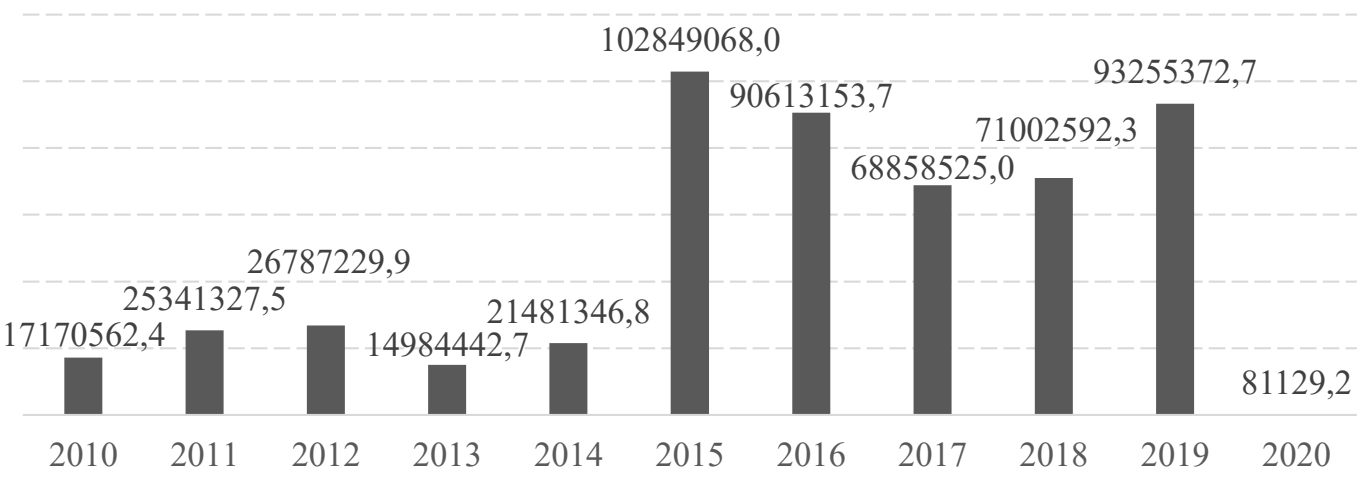

- Net profit (loss) of agricultural enterprises, thousand UAH

FIGURE 2 Dynamics of net profit (loss) of agricultural enterprises of Ukraine for 2010-2020 Source: developed on the basis of data from the State Statistics Service of Ukraine [2]

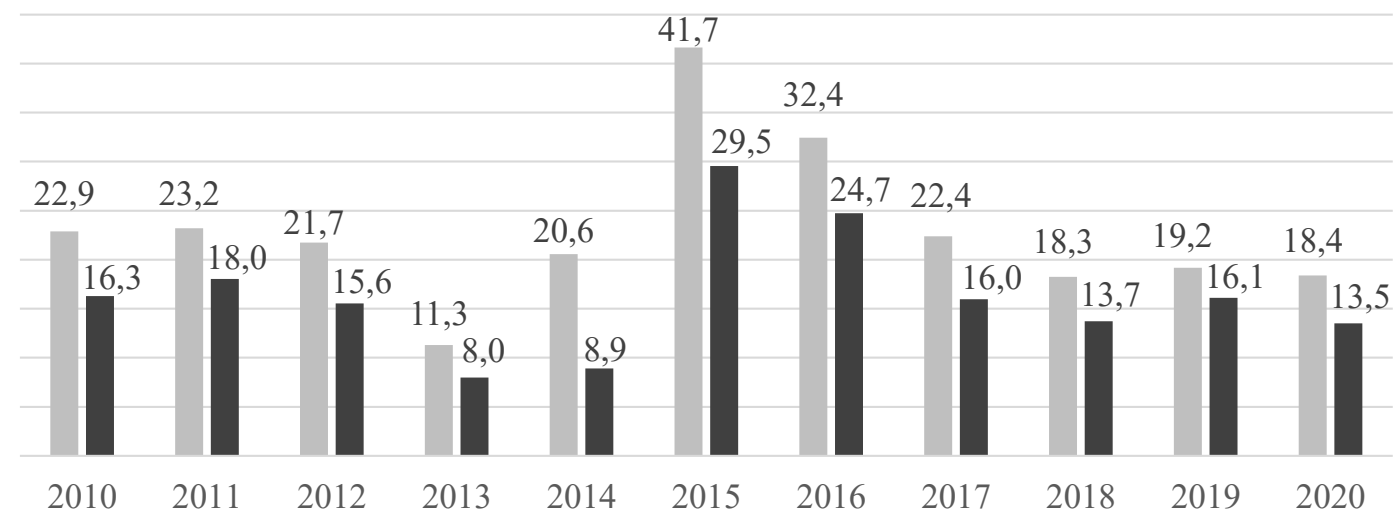

The level of profitability (loss) of operating activities of agricultural enterprises

- The level of profitability (loss) of all activities of agricultural enterprises

FIGURE 3 Dynamics of net profitability (loss) of agricultural enterprises of Ukraine for 2010-2020 Source: developed on the basis of data from the State Statistics Service of Ukraine [2]

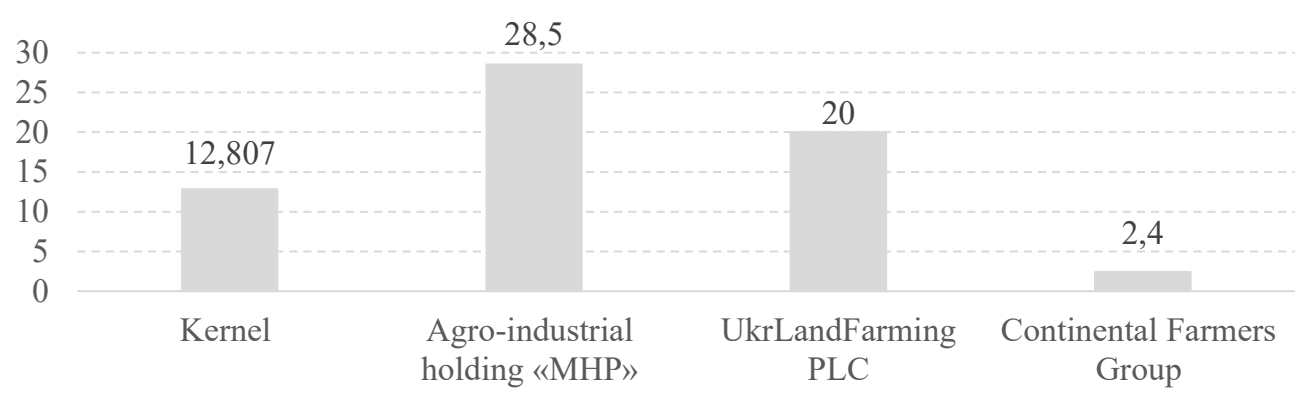

Number of employees, thousand people

FIGURE 4 Number of employees of leading agricultural holdings of Ukraine in 2020, thousand people

while in terms of capacity and number of employees it was significantly ahead.

Thus, the agricultural sector has significant potential for further growth, but a number of problems hinder its development. The stimulus is the system of land use and land relations through the lifting of the moratorium on land purchase and sale.

However, it is currently difficult to draw conclusions about the implications of such reforms, as there are no clear and transparent rules of the "game» in the sector. It is known that the most powerful participants in the agricultural market are agricultural holdings. Despite some difficulties caused by internal and external factors, they do not give up their intentions to build infrastructure and expand their influence in foreign markets. The agricultural sector generates $15-20 \%$ of GDP annually, and despite the crisis of recent years, provides the population of Ukraine with quality products of its own production. 


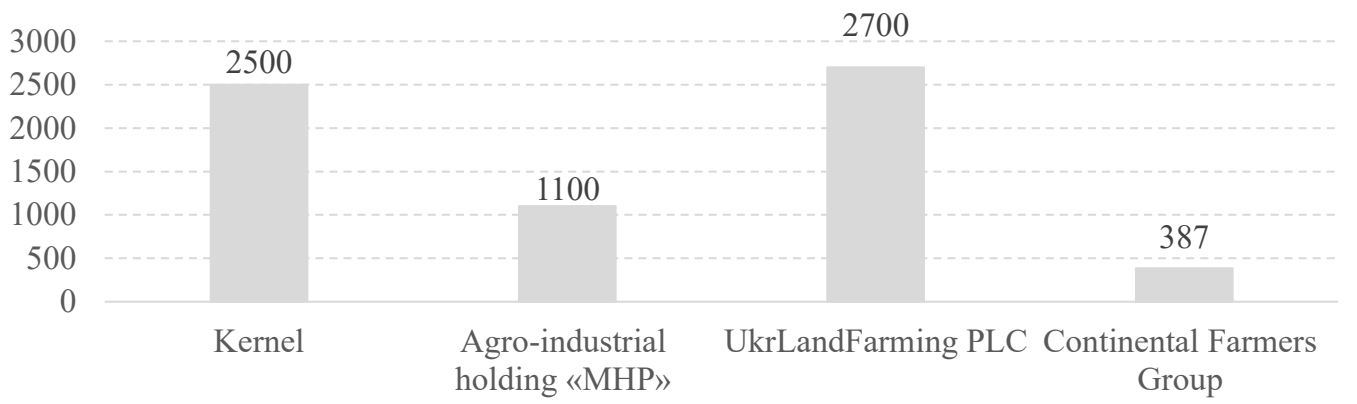

Capacity for storage of products, thousand tons

FIGURE 5 Capacity for storage of products of the leading agricultural holdings of Ukraine in 2020, thousand tons

\section{Methodical approaches to forecasting changes in the structure of assets and capital}

Given the inertia of the economic potential of economic entities, the high dynamics of changes in the situation of almost all market institutions in financial analysis special attention is paid to forecasting changes in the structure of assets and capital. Although in this change there is a certain interdependence, primarily in the certainty of the ratio of equity and debt capital in the formation of the necessary non-current and current assets, but the internal structuring of assets and liabilities is determined by the action of such internal and external factors [4]:

- sectoral features of the enterprise and its statutory parameterization in the choice of economic activities. At the same time, the share of non-current assets will prevail in capital-intensive industries, and the share of current assets will prevail in material-intensive industries and spheres of circulation. When the ratio of operating investment and financial activities changes, there will be an adequate restructuring of current assets;

- intensification of production and circulation can lead to an acceleration of the operating cycle of productive activities and to an increase in the share of borrowed capital from funding sources;

- the life cycle of the enterprise and its mission in its various phases will cause structural changes in assets and capital, which involves a balanced assessment of depreciation of policy, mobility management of their operational convertibility, marketing activity and business partnership development, etc. Thus, in the recovery phase, the structuring of assets is carried out in the direction of increasing production capacity. In the stabilization phase structuring is associated with ensuring financial stability and competitiveness, and in the recession phase - in achieving the solvency of the enterprise;

- change in the situation of commodity and financial markets, which affects the ability to raise capital, the formation of inventories, the state of receivables and payables, the level of business activity and immobilization of funds;

- profitability of activities that create conditions for increasing the share of equity, minimizing current liabilities, participation and the stock market, etc.

In methodological terms, analytical assessments of the forecast of changes in the structure of assets and capital involve the study of trends and patterns of certain structuring, which are extrapolated to the future and the necessary expert assessments. Forecasting structural changes in assets and liabilities involves the use of structural analysis methods with the calculation of pessimistic, optimistic and realistic forecasts. The most common is the calculation of long-term changes in the structure of assets and liabilities based on the parameters of the correlation of financial indicators of assets and liabilities to the projected sales volume.

Such system of indicators should be used for these calculations:

$T_{o}$ - growth rate of production and sales, coefficient;

$T_{c}$ - growth rate of product prices, coefficient;

$B_{p r}$ - projected volume of operating expenses, which is calculated in relation to the increase in the volume of activity, changes in prices, tariffs and standards of deductions for social needs and depreciation, thousand UAH;

$A_{n o}$ - non-current assets at the beginning of the forecast period, thousand UAH;

$K B$ - projected volume of investments, thousand UAH;

$\tau_{a}$ - average depreciation rate of non-current assets, coefficient;

$T_{3}$ - duration of inventory turnover, days;

$T_{q_{3}}$ - duration of collection of receivables, days;

$q_{\mu n}$ - average share of retained earnings in total sales profit, coefficient;

$P_{o}$ - basic volume of production and sales, thousand $\mathrm{UAH}$;

$K_{c}$ - registered and annual invested capital of the enterprise, thousand UAH.

Based on these indicators, the projected amount of assets and capital will be determined by the algorithms presented in table 1.

The projected value of long-term and short-term loans and credits is taken when forecasting at the level of the base period. If there is a real forecast of long-term and short-term capital raising, appropriate adjustments are made in the calculation of the projected amount of capital $\left(K_{n p}\right)$.

Similarly, the amount of registered or other invested capital is determined. The results of forecasting changes in the structure of assets and capital largely depend on the completeness and quality of the initial data, which are included in the calculation of projected indicators. This is largely influenced by the projected dynamics of sales, changes in prices and tariffs for products, raw materials, materials, energy, real investment, etc. From here follows the risk of structuring assets through equity and borrowed 
TABLE 1 The sequence of calculation of the projected volume of assets and capital of economic entities

\begin{tabular}{|c|c|c|}
\hline \multicolumn{2}{|r|}{ Name of items of assets and capital } & The sequence of calculation \\
\hline 1. & The value of non-current assets at the end of the forecast period $\left(A_{n p}\right)$ & $A_{n p}=A_{n o}+K B-A_{n o} \times P_{o}$ \\
\hline 2. & The volume of inventories $\left(3_{n}\right)$ & $3_{n}=\frac{P_{o} \times\left(1+T_{o}\right) \times\left(1+T_{c)}\right.}{365} \times T_{3}$ \\
\hline 3. & Projected amount of receivables $\left(D 3_{n}\right)$ & $D 3_{n}=\frac{B_{p r}}{365} \times T_{q 3}$ \\
\hline 4. & Projected amount of cash and short-term financial investments $\left(G_{n}\right)$ & $G_{n}=K_{p r}-A_{n p}-3_{n}-D 3_{n}$ \\
\hline 5. & Projected amount of equity $\left(B K_{n}\right)$ & $B K_{n}=K_{c}+\left[P_{o} \times\left(1+T_{o}\right) \times\left(1+T_{c}\right)-B_{p r}\right]$ \\
\hline 6. & Projected amount of accounts payable $\left(K 3_{n}\right)$ & $K 3_{n}=\frac{B_{p r}}{365} \times T_{k 3}$ \\
\hline 7. & The total amount of capital to cover assets & $\begin{array}{l}K_{p r}=B K_{n}+K_{g}+K_{k}+K 3_{n} \\
K_{k}-\text { projected long-term loans and credits, thousand UAH; } \\
K_{g} \text { - projected short-term loans and credits, thousand UAH. }\end{array}$ \\
\hline
\end{tabular}

capital. Therefore, different approaches to financing policy are used in forecasting these structural changes. Most often, three approaches are used: conservative, aggressive and compromise.

In solving the problems of structuring assets and ensuring their growth, the formation of enterprise capital and optimization of its structure is crucial. In financial analysis, when making promising management decisions, several concepts are considered: the concept of minimizing capital raising; the concept of integrated assessment of the amount, time and risk of raising capital; the concept of «the effect of financial leverage» [4].

When forecasting the volume of capital attraction according to the concept of its minimization, the volume increase is calculated from: the issue of preferred and ordinary shares; bond issues; financial leasing; bank loan; commodity credit.

Forecasting the capital structure according to the concept of "financial leverage" is associated with the calculation of the marginal feasibility of raising capital in the form of long-term and short-term leases and loans to cover the assets of the enterprise. The criterion for assessing the feasibility of raising is an increase in return on equity due to the use to cover these loans and asset loans.

It should be borne in mind that the company benefits from the use of borrowed capital in the presence of objects of such financing in any case. However, when there is a positive characteristic of the feasibility of such involvement, at the same time there are created the conditions for increasing the return on equity. That is, if under such favorable conditions the company does not use loans, it reduces the economic efficiency of its activities as a whole.

The positive effect of financial leverage is achieved when the interest on borrowed capital is lower than the return on capital, which is advanced to the activities of the enterprise. That is, there is a positive balance between return on invested capital and the average cost of borrowed capital. This difference is also called the financial leverage differential. In addition, the total value of the effect depends on the degree of taxation of enterprise profits and the ratio between the amount of borrowed and equity (financial leverage) [4].
Taking into account the tax burden on income is necessary in cases where income tax rates of different activities are differentiated, tax benefits are provided, or if certain structural units of the enterprise operate in free economic zones and in countries with other income tax rates.

Taking into account the action of financial leverage is due to the fact that the size of the differential depends on the risk of raising capital. The greater the amount of capital, the lower the financial stability of the enterprise, and this is the basis for increasing the interest rate on the loan by lenders, who thus insure their risk.

Thus, given these circumstances, the calculation of the effect of financial leverage $\left(E_{l}\right)$ will be:

$$
E_{l}=\left(R_{k}-C_{k r}\right) \times(1-r) \times \frac{3 K}{B K}
$$

where $R_{k}$ - return on invested capital, \%;

$C_{k r}$ - the average interest rate on borrowed capital, \%;

$3 K$ - attracted capital of the enterprise, thousand UAH;

$B K$ - equity of enterprises, thousand UAH.

Taking into account the inflation index $\left(I_{i}\right)$ this calculation will have a modified form:

$$
E_{l}=\left(R_{k}-\frac{C_{k r}}{1+I_{i}}\right) \times(1-r) \times \frac{3 K}{B K}+\frac{3 K \times I_{i}}{B K \times\left(1+I_{i}\right)}
$$

However, it should be borne in mind that the main source of achieving quality structuring of assets and capital is the profit of the enterprise, which remains at the disposal of the enterprise. In a financial crisis, raising capital carries significant risks of losing financial stability. Therefore, the main attention in the formation of economic development strategy in terms of building property potential should be paid to the mobilization of growth reserves, profits for all activities.

\section{Conclusions}

As a result of the analysis of the dynamics of indicators that characterize the general trends of agricultural enterprises in Ukraine, negative trends were revealed due to the aggravation of economic crises, hostilities in the east, the annexation of the Autonomous Republic of Crimea, destabilization of social and political life, pandemic COVID-19. It is determined that the main reason for this 
situation is the bankruptcy of domestic enterprises due to the low level of competitiveness and the inability to adapt to changing external and internal environments and attract investment.

In the course of the research, indicators were proposed for the calculation of perspective changes in the structure of assets and capital based on the parameters of the correlation of financial indicators to the projected sales volume. The system of indicators includes the following: growth rate of production and sales, growth rate of product prices, projected operating costs (calculated relative to the growth of activity, changes in prices, tariffs and norms of deductions for social needs and depreciation, non-current assets at the beginning of the forecast period, the projected volume of investments, depreciation rate of non-current assets, duration of turnover of inventories, duration of collection of receivables, the average share of retained earnings in total profit from the basic volume of production and sales, registered an annual invested capital of the enterprise.

It is determined that the main source of achieving quality structuring of assets and capital is the profit of the enterprise, which remains at the disposal of the enterprise. In a financial crisis, raising capital carries significant risks of losing financial stability. Therefore, we propose to pay attention to the mobilization of reserves of growth, profit for all types of activity when forming the strategy of economic development in terms of building property potential.

\section{References}

[1] Skopenko, N. (2018). The main directions of overcoming the negative trends in the development of agro-industrial complex of Ukraine. E-source: http://jrnl.nau.edu.ua/index.php/PPEI/article/download/294/283

[2] State Statistics Service of Ukraine. E-source: http://www.ukrstat.gov.ua/

[3] Top 10 largest agricultural holdings in Ukraine in one infographic (2021). E-source: https://bakertilly.ua/ news/id49433

[4] Mnykh, E. V., \& Barabash, N. S. (2014). Financial analysis: a textbook. KNUTE, 536 p. (in Ukrainian)

[5] Lupenko, Yu. O. (2015). Current state and prospects of the international integration of the agrarian sector of Ukraine: the problem of agroeconomic science. Ekonomika APK, 6, 6-10. (in Ukrainian)

[6] Pugachev, M. I. (2017). Agrarian sector of Ukraine's economy in the context of institutional change. Ekonomika APK, 5, 12-18. (in Ukrainian)

[7] VEZHA (2019). Ukraine is among the three main suppliers of agricultural products in the EU. E-source: https:/vezha.net.ua/suspilstvo/ukrayinav-trijci-osnovnix-postachalnikiv-agroprodukciyi-do-yes/

[8] Lupenko, Yu. O., \& Mesel'-Veselyak, V. Ya. (eds.) (2012). Strategic directions of development of agriculture of Ukraine for the period up to 2020. Kyiv: National research center «Institute of agrarian Economics», p. 218. (in Ukrainian)

[9] Ukrainian club of agricultural business (2018). Conducting agribusiness in Ukraine. E-source: http://ucab.ua/files/ Survey/Doing/DoingAgribusinessInUkraine_2018 